\section{Love, Sex, Communism: A Discussion}

|Jules Joanne Gleeson, Jose Rosales and Andrew Culp

\section{Bionotes}

Jules Joanne Gleeson is a researcher based at the University of Vienna. Her work focuses on the comparative history of both pre-modern and contemporary gender relations. Recently published work includes a genealogy of gender abolitionary politics for Blind Field: A Journal of Cultural Inquiry, two pieces on right-wing internet culture for The New Socialist, and a queer materialist reading of the "transgender moment" for Viewpoint Magazine. She is currently completing a thesis on the exclusion of the female and effeminate from Byzantine Mount Athos.

University of Vienna, Technical University Dresden julesinwien@gmail.com

Jose Rosales is a Doctoral Candidate in Philosophy at Stony Brook University. His dissertation is a partisan reading of Deleuze and Guattari's political philosophy where he argues that any so-called "Deleuzoguattarian" politics is fundamentally grounded on their commitment to an anti-state, revolutionary vision of communism. His other writings include "Of surrealism and Marxism" in Blind Field: A Journal of Cultural Inquiry, "Die Schwarze Block Nicht War" in Riot - Was War Da Los In Hamburg? (Laika/NON.Derivate, 2018), and "Relearning to Hate the World - Dark Deleuze Book Review," Deleuze and Guattari Studies, Vol. 12, No. 3 (2018).

Stony Brook University, University of Westminster jrosalesmailbox@gmail.com
Andrew Culp (PhD, The Ohio State University) teaches in the MA Program in Aesthetics and Politics at the California Institute of the Arts. His first book, Dark Deleuze (University of Minnesota Press, 2016), recovers the hidden negativity of the thinker Gilles Deleuze to challenge today's world of compulsory happiness, decentralized control, and overexposure, and it has been translated into numerous languages.

California Institute of the Arts aculp@calarts.edu

The following discussion arose from a chance encounter now routine for a generation raised by the internet. Emerging from a common interest in ultra-left politics, queer social life and the isolation of academia, the conversation unfolded online with the participants typing away on a shared document while researching resources on-the-fly and holding side conversations over chat. The style of their remarks demonstrates how scholars are now fusing traditional forms of thought with the tools of digital culture, as their high-minded observations are punctuated by quotes from online anthologies, page numbers quickly culled through machine searching, and references provided by hyperlink as encouragement for readers to complete their own deep dive into the material. As such, perhaps the reader should imagine it less as an academic panel discussion and more like a post with threads, replies, likes, and links. 
Question: Marxism has become increasingly popular in many places since the 2008 financial crisis in the US and its global economic repercussions. Almost ten years after that crisis, what have we seen happen? Do we still see the winds moving in that direction?

Jules Joanne Gleeson: The last ten years have re-forged Marxism profoundly, and to an extent which deserves careful surveying. Marxist groups have largely entered a state of disarray, often scandalized by in ways I could spend the rest of this piece listing and analyzing. The leadership of many Marxist groups have been left entirely discredited by their handling of, and often involvement in, alleged sexual abuse. This has called into question the leadership of many of the more hierarchical organizations, most notably the UK's SWP. (But "horizontalist" scenes have also struggled, and mostly failed, to resolve questions around protection of participants against peer group sexual predation.) In short, the last ten or so years have not treated Marxist organizations kindly.

However, Marxist thought has entered something of a renaissance, especially in light of the ease of distribution of key texts, and the proliferation of informal study groups and book clubs for working through this oftenchallenging material. One obvious example is the Communist Research Cluster, who produced a number of free PDF readers ${ }^{1}$ which were read in circles around the US ( I was briefly running sessions for their Revolutionary Feminist Reader here in Vienna). In this respect, Marxist theory has extended itself markedly.

Jose Rosales: I think what Jules has said regarding the discrepancy between the disarray of Marxist groups/organizations and the renaissance of Marxist theory is one of the clearer and more defining features of the "state of Marxism" since the 2008 crisis. This discrepancy is perhaps even starker when one contrasts the example she quite rightly gave of the scandals that plagued the UK'S SWP with the crowds that were drawn to the Idea of Communism conference in March 2009 at London's Birkbeck institute: the conference originally booked a room for 180 while the conference was attended by upwards of 1200 people.

While it may be interesting to spend some time giving a materialist analysis of the way in which the popularity of the very word Communism acts as a means of publishing houses to gain popularity with a wider readership and ultimately sell more books, this might not be that helpful since it tempts leftists of various stripes to point fingers at each other rather than understand where and how Marxist theory is actually being connected to concrete prac-

1 Available at WwW.communistresearchcluster.wordpress.com/ readers. 
tices. One example of this from the many places Marxism has regained popularity and readership, and one that comes just off the heels of the 2008 financial crisis, can be seen in the experiences of the activists who participated in Iran's 2009 Green Revolution. Why is the experience of activists during the Green Revolution important for helping us understand how the growing theoretical interest in Marxism has been connected to a larger political project? The answer to this question is given by the figure of the interrogators who would question arrested activists and civilians. Now, it was quickly discovered by those who were arrested that their interrogators were not simply doing the work of the State; darker and more profound was their discovery during their interrogations that these were individuals hired by the state and trained in the very discourses and theories of the very Marxist and/or Communist thinkers who have gained such popularity since 2008 Žižek, Badiou, Laclau, Negri, Althusser and so on. Thus, while it is true that there is a certain disconnect between Marxist organizations and their corresponding theoretical frameworks after 2008, this does not mean that the increased circulation, translation and popularity of Marxist theory has failed to link up with actual, concrete, practices. In this instance, however, theory has been related to a praxis that remains hostile and absolutely incommen- surable with the project envisioned by Marx himself or by present day Marxist theorists. So, it appears that the status of Marxism today is one of a political position that is met with almost an equal degree of interest as well as hostility.

Andrew Culp: We seem to be caught between two very different stories about Marxism. On the one hand, Marxism appears as the antidote to the illnesses of our political moment. This is Marxism's diagnostic power - it points to the source of our problems. I think that the diagnosis matches the political in which we have found ourselves: financialization feels inescapable, there is wide dissatisfaction toward politicians in general and politics writ large, and it feels like there is a whole system set against us. While on the other, we are told that the twentieth century has proven Marxism to be a dead-end. There is some truth to that tale. I do not think that Marxism has recovered from the fall of the Soviet Union and the rise of neoliberalism. Yet I agree with Herbert Marcuse that we have learned the wrong lessons from the Soviets - its failure came from an obsessive focus on economic production, which elevated it to a moral principle subjectively hardcoded into citizenship. Neoliberalism extends the hangover from the fall of the Berlin wall, not only because of its devastating material consequences, but because it has 
effectively convinced so many that "there is no alternative" to financial logic. What a cruel legacy given that communism is meant to be the antithesis of economics.

To me, the recent popularity of Marxism speaks of a growing communist aspiration. We finally seem to be at a point where the failed economic and political strategies of historical communist experiments are being thrown off. New communisms are arising every day. Just look at the communism that has grown out of the "weird" internet: odd corners of tumblr, dank memes stashes and reading groups that fuse together monstrous communisms that would have horrified the First International. This is the future, and it is up to us to join in or be left behind.

JJG: I am sure that I am not alone in having first encountered key ultra-left texts such as End Notes, LIES, the Bash Back! Reader and Tiqqun online. Various communities exist primarily for working through this often-challenging material. Outlets like Ritual Magazine, Viewpoint Magazine and New Socialist or theoretical works such as The Xenofeminist Manifesto or Nihilist Communism (as well as countless polemical "interventions" stored on LibCom) have only ever been published as material on the web. While this is nothing new in one sense (small scale polemical print runs have always been a key leftist activity), the breadth and range of revolutionary material universally available online has caused a striking expansion of intellectual engagement with Marxist thought.

AC: As Marxists working in the academy, I am sure that we have all struggled with how to address these alternative materials. Academic Marxism can be very conservative in that it wants to establish a clear ancestry of credible thinkers and does not immediately suggest how to treat texts distributed through venues such as blogs, small presses, and online reading groups; except maybe to treat them as "outsider" writing. How have you two negotiated the tension?

JR: First, I just wanted to add what may be a more balanced and helpful counter-example to the one of the interrogator I gave above. In contrast to this example, it is worth mentioning as a counterpoint the publication of Nick Srnicek and Alex Williams's Inventing the Future ${ }^{2}$ (a text also published by the same publishing house that puts out the works of Badiou, Žižek and the like) - if only due to the fact that it was a text that understood itself as belonging to this tradition of Marxist theory while also being a text that made a link between itself and a larger political project. Now, the larger political project here is the one of a Corbyn-led Labor Party with the hope that if

2 Nick Srnicek and Alex Williams, Inventing the Future: Postcapitalism and a World without Work (London and New York: Verso, 2016). 
Corbyn was elected as Prime Minister, the kinds of strategies and analyses found in Inventing the Future could then serve as the horizon of the Party's struggle and aid in the implementation of a set of policies that would ameliorate the suffering of an increasing number of the UK population. Now, despite (fundamental) disagreements with such a project, I still think this is an important example that helps us understand where and how the increasing production of Marxist theory is finding the means for having actual, material, consequences.

Second, while the attraction of blogs and small presses is that one can produce writing without having to spend valuable time waiting to hear back from a review committee while still being in conversation with one's peers, it has the potential to also tempt academics and writers to begin to hold themselves to an impossibly high standard: namely, by measuring the content and potential of their work in terms of how often they can post new content. When quantity trumps quality, then once potentially radical mediums of publishing and writing begin to mirror the "'bourgeois' media: constant data flow, information overload and obsolescence, sensationalism... Radicality is reduced to a description and exaltation of manifold struggles." 3 Perhaps it is just as

3 Gilles Dauvé and François Martin, "The Bitter Victory of Councilism," in Eclipse and Re-emergence of the Communist Movement (Oakland, California: PM Press, 2015), 129-33, necessary for writing as it is for political organizing to know when one has outgrown the usefulness of a certain medium or form if only to avoid the prolongation of that which has been longing to die.

JJG: My scholarly writing has two faces, which maybe do not overlap as much as I would like to.

Professionally, I have spent my (short) career in Byzantine Studies, and comparative medieval history institutes. There are several prominent Byzantinists who take a Marxist approach to social history. The most famous as Marxists are John Haldon and Jairus Banaji. Haldon produced an innovative comparative theoretical monograph entitled The state and the Tributary Mode of Production in 1993, a time when historical materialist inquiry could not have been less fashionable. ${ }^{4}$ While certainly not the last word on pre-modern political economy, Haldon makes a convincing case that the tributary mode can be distinguished by a lack of modal distinction between rent and taxes. (In other words, being taxed by the state or charged rent are undifferentiated at the point of surplus extraction, i.e., peasants being stripped of their excess produce.) Banaji was a veteran of the "Mode of Production" debates in India, who turned his attention to agrarian

131.

4 John Haldon, The State and the Tributary Mode of Production (London and New York: Verso, 1993). 
relations on Byzantine estates for many years. Banaji has done much to refocus Marxist theory around historical inquiry, and more than any living thinker has revived interest in Marx's focus on political economy's "laws of motion." Both recently debated Banaji's masterful Theory as History in a productive symposium hosted in the Historical Materialism journal. ${ }^{5}$ While less prominent as Marxists, two of my former supervisors - Peter Sarris and Dionysios Stathakapolous - also use an historical materialist approach to Byzantine historical sources. Despite this, the field as a whole is still in a state of recovery from the influence of logical positivism. "Theory" is often viewed with skepticism, considered a potential distraction, and treated as an element which needs to justify itself. This seems unlikely to change completely for the foreseeable future, as much of the work required to advance the field's accessibility is outstanding translations, production of critical editions, etc. (Work for which philology is indispensable.) So when writing in this mode, I need to make careful efforts to justify each theoretical step. On the upside, this keeps me on my toes.

Secondly, and somewhat separately, I have been producing Marxist feminist writing for some years now. My primary inspiration is the

5 See Historical Materialism, Vol. 21, Issue 4 (2013), available at Ww.historicalmaterialism.org/journal/ volume-21-issue-4-2013. approach of Cinzia Arruzza, in her "Remarks on Gender."6 This remarkable piece effectively stitches together a disparate and non-continuous body of material into "Three Theses." While this approach could be dismissed as reductive, the outcome is an introductory piece which effectively stages what might be called a "benign fabrication." Presenting a disjointed series of debates which originally took place across decades, and across disparate discursive and political contexts, in a new form which might be read through in an afternoon. (I think this work is valuable, whether or not one agrees with Arruzza's decisive siding with the "Unitary" approach to gender/capital.) These reconstructions can render previously esoteric debates newly accessible and can clarify divergences of position between like-minded scholars.

In a similar vein, I have done my best to include and respond to material which is normally outside of the "canonical" approach to thought Andrew mentions. A large part of my 2015 piece (written with Kate Doyle Griffiths ${ }^{7}$ )

${ }^{6}$ Cinzia Arruzza, "Remarks on Gender," Viewpoint Magazine, Issue 4 (September 2, 2014), WWW.viewpointmag. com/2014/09/02/remarks-on-gender.

7 Kate Doyle Griffiths and Jules Joanne Gleeson,

"Kinderkommunismus. A Feminist Analysis of the TwentyFirst-Century Family and a Communist Proposal for its Abolition," Subversion Press, June 30, 2015, WWW. subversionpress . wordpress . com/2015/06/30/ kinderkommunismus. A translation into French by Félix Boggio Éwanjé-Épée was published as: "Kinderkommunismus. Une proposition communiste d'abolition de la famille," en Pour un féminisme de la totalité, coordonné par 
engages with a mode of gender politics I call "Queer Rejectionism," which dominates many queer scenes while rarely appearing in published scholarly works. In a 2017 piece published by Viewpoint Magazine, "Transition and Abolition," 8 I address a range of cultural (and socially reproductive) texts produced by transgender authors. And in a pair of pieces I wrote for the journal Blind Field on the history of gender abolition, I attempted to draw into wider view a range of material from both the queer New Left and contemporary transfeminism, which previously had received little attention. My hope here is to bring material previously unmentioned in Marxist theory to the attention of other communists who share my concerns. This is retrieval work.

In short, I have dealt with academic Marxists primarily by avoiding them .

AC: For a while I was worried that the academy is where knowledge went to die. There are so many examples of academics poaching concepts from the streets. And I do not just mean the disgusting colonial practice of anthropology that make careers off others' knowledge. There is a tendency for the academy to mince

Félix Boggio Éwanjé-Épée, Stella Magliani-Belkacem, Morgane Merteuil et Frédéric Monferrand (Paris: Éditions Amsterdam/Collection Période, 2017), 221-42.

8 Jules Joanne Gleeson, "Transition and Abolition: Notes on Marxism and Trans Politics," Viewpoint Magazine, July 19, 2017, WWw.viewpointmag.com/2017/07/19/transition-andabolition-notes-on-marxism-and-trans-politics . theories when they are incorporated. Consider what has happened to intersectionality, a concept developed as a response to the silencing of black women's voices in activist spaces. Imagine my surprise when, a couple years ago, I heard that intersectionality was taught in the dorms to all incoming students as "everyone has a different story to tell." What a transformation! A concept initially developed to foreground the experience of specific groups had been translated into a liberal democratic idea that everyone basically stands on the same footing.

But then I began to think much more about Marx's old mole, who burrows underground only to emerge in times of revolution. There is an ultra-left idea that as thinkers, we are not the ones who will make revolution (if and when it is made). Rather, we always circulate on the margins, with our influence always being unexpected and contingent. In part, I think Fred Moten and Stefano Harney are right to suggest that the only relationship to the contemporary university is a criminal one, which is to say, to embrace the position of being caught in a state of exception. We must assume that whatever politics we incorporated into our work can only get us in trouble with the institution (and just look at how the alt-right has been getting people in trouble lately!), while also knowing that meaningful work requires us to stick our 
necks out. And even if we remain modest about our influence on the current situation, at the very least, the academy puts us in a unique position to keep the idea of revolution alive in counter-revolutionary times. Bit rot, the impermanence of collective and a disregard for archiving already strikes a pretty big blow to the lifecycle of alternative materials. Just last week, I was trying to track down materials lost with the disappearance of zinelibrary. info. If that is the case, then maybe it is our job to sneak in as much of the street as we can.

JJG: Much as the "Whiggish" view of history was said to present a linear arc of positive changes (erasing or dismissing setbacks and calamities), vulgar feminist history makes the black lesbians who founded so many revolutionary US groups vanish from view as it shuffles along its business. Gay male popular history by contrast attempts to eliminate lesbians altogether. (Note the ahistorical absence of women in Gus Van Sant's Milk. When, as C.A. Conrad notes, lesbians in fact ran the "back end" of Harvey Milk's mayoral run.)

AC: Perhaps it is that erasure that demands a turn to queerness? Eve Sedgwick argues in the introduction to Epistemology of the closet that early theories of same-sex desire meant that "there were essentially no valid grounds of commonality between gay male and lesbian experience and identity."9 She says that the two worlds have to be brought together: first, through challenges to idealized notions of femininity in "the Sex Wars" of the 1970s and increased visibility of trans and butch identities (leading to the invention of a separate axis of sexuality distinct from gender); and second, with the coalitions forged in the 1980s in which lesbians joined with gays during the AIDS crisis to provide a unified response to homophobia. Queer identity is the immediate product of these struggles, but after being in use for decades, it still has trouble living up to its legacy of fighting for a truly common space for all genders and sexualities.

Question: What opportunities does Marxist feminism offer us for a new sexual politics, or new kinds of love?

JR: It is my suspicion that one way in which Marxist feminism could be understood as offering a new understanding of the relationship of work and sex, or work and love, is on the basis of how Marxist feminism has been able to deepen the specificity of what exactly a communist politics promises and entails. The example that immediately comes to mind here is Silvia Federici's seminal essay "Wages against

9 Eve Kosofsky Sedgwick, The Epistemology of the closet (Berkeley and Los Angeles: University of California Press, 1990), 36. 
Housework." It is in this essay where Federici makes a comment that appears as nothing but a passing remark; a statement that is less a materialist description and more a declaration regarding just what exactly is entailed and implicitly asserted in the project of bringing about a communist future. So, and in the course of her analysis, Federici writes: "[W]e want to call work what is work so that eventually we might rediscover what is love and create our sexuality, which we have never known."10 Given Federici's insight, and inquiring into the opportunities afforded to us by Marxist feminism, we could begin by attempting to understand the precise sense in which she makes this remark. In other words, is it the case that Federici is implicitly arguing for a view that seeks out the meaning and social relations of love, intimacy, and familial bonds, insofar as they are stripped of their determinations by the social relations of capital?

My suspicion, however, is that the question with which Federici is occupied is one that is as difficult and profound as it is simple and concise: What would it mean to love as a communist? To love like a comrade, or as someone in solidarity, or as someone in a romantic relationship? And what are the modes of

10 Silvia Federici, "Wages against Housework," in Revolution at Point Zero: Housework, Reproduction, and Feminist Struggle (Oakland, California: PM Press, 2012), $15-22,20$. loving, both ourselves and others, that are made possible only by virtue of communism? This is to inquire into the possibility of an image of communism as one that is irreducible to its being the solution to the riddle of history. So, if what is implied by Federici's remark is that communism is the historical condition upon which questions of love and sexuality can be posed, in its most profound and meaningful manner, then what is potentially discovered within the tradition of Marxist feminism more generally is a vision of communism as something more than historical resolutions; a communism that was to be the very condition through which the meaning and function of love no longer derives its sense or value through its participation in a time no longer defined as that of labor or of leisure.

And so, regarding the connection between love and the form of time adequate to it, and with respect to Federici's insistence on the political necessity of maintaining a clear separation of the time of work from that of sex/love/life, we catch a glimpse of how this Marxist feminist analysis of the relationship between production and reproduction are immediately related to Marx's own position on the differing forms of time proper to capitalism and communism. For example, Marx makes a relevant observation in the Grundrisse when he writes that: "For real wealth is developed pro- 
ductive power of all individuals. The measure of wealth is then not any longer, in any way, labor time, but rather disposable time."11 This disposable-time that is said to be the true measure of the wealth produced under communism; this time with which we can do as we please and that structures one's life as a life defined by this form of time that can only be attributed to communism; this time, then, is the form of time that not only corresponds to Federici's separation of sex from work but does so in a way that moves beyond the brute opposition of labor-time vs. leisure-time (which is simply unwaged time put in the service of reproducing labor-power). In this way, one would be able to see how disposable-time is the form of time adequate to communism; as the form of time most adequate for a communist determination of the questions and experiences surrounding love and sexuality; as the form of time proper for our rediscovery of love, for the creation of sexualities we have never known.

AC: It is undeniable that Marxist feminism has been essential in expanding the category of reproduction. Moreover, Marxism was historically at the forefront of "the woman question." But I am curious why queer Marxism seems far less explored in writing than socialist feminism. This is even more surprising giv-

11 Karl Marx, Grundrisse, trans. by Martin Nicolaus (London: Penguin, 1973), 708. en that political lesbians have almost always been on the forefront of socialist feminist thought. Of course, one could say that reproduction was queer from the beginning. Yet this seems emblematic of most work that could pass as queer Marxism: either the queer theory or the Marxism seems to be brought in through the back door under a different sign.

JJG: In a typical historian's style, I would suggest that we can best approach a new sexual politics by grasping and reviewing some old ideas, and critically reviewing bygone disputes. It may help to return to the notorious Sex Wars and provide an account of that ructious episode. Although much discussed in generalities, relatively little systematic history has been done on the crisis caused to lesbian feminism by Sadomasochism (S\&M).

One exception is A.S.G. Robinson's thesis Passion, Politics, and Politically Incorrect Sex: Towards a History of Lesbian Sadomasochism in the USA 1975-1993.12 This history is written from a queer perspective, but in an even-handed fashion (not dismissing or neglecting evidence from the anti-S\&M wing). From a black feminist perspective, Amber Jamilla Musser's Sensational Flesh: Race, Power, and Masochism reads a

12 A.S.G. Robinson, Passion, Politics, and Politically Incorrect Sex: Towards a History of Lesbian Sadomasochism in the USA 1975-1993 (Master's Thesis, Budapest: Central European University, 2015), wWw.etd.ceu.hu/2015/robinson_ anna.pdf. 
wide range of material to produce a compelling case for the enmeshed condition of masochism and racialization. The writings of Pat Califia and Dorothy Allison of course provide views from inside the dispute. (Allison's intensely personal essays "Public Silence, Private Terror" and "A Question of Class" are both sorely neglected by most feminists.) Mark Thompson's Leatherfolk collection gathers a startling range of perspectives from the early 1990s, when queer S\&M was still in its prime. (By the end of the 1990s these practices had been "straight-washed" in many places.13)

Especially interesting for us is that two figures on either side of the Sex wars at once drew from Marxist theory and sit awkwardly within the canon of Marxist feminists: Audre Lorde and Gayle Rubin. Rubin's famous essay "The Traffic in Women" tested the limits of Marxist theorization to explain gender, introducing structuralist conceptions of kinship which have proven widely influential. Lorde was a remarkably effective socialist organizer, and also scathingly attacked S\&M lesbians. But this

\footnotetext{
13 Amber Jamilla Musserm, Sensational Flesh: Race, Power, and Masochism (New York: New York University Press, 2014); Dorothy Allison's "Public Silence, Private Terror" can be found in Skin: Talking about Sex, Class and Literature (New York: Firebrand Books, 1994), 10119; Allison's "A Question of Class" (also originally published in Skin) can be accessed online at History Is A Weapon, no date, WWW.historyisaweapon.com/defcon1/ skinall.html; Mark Thompson (Ed.), Leatherfolk: Radical Sex, People, Politics, and Practice, revised edition (Los Angeles: Daedalus, 2015).
}

was founded in the limits of Lorde's own theory of sexuality, outlined in the classic essay "On the Uses of the Erotic," which should be engaged with by all queer feminists. What united both sides of the Sex wars was a belief that major victories could be won in the field of sexuality. I worry that this belief has ebbed or has been ceded to liberal feminist "sex positivity." I think a work of this recovery could be very helpful in returning us to revolutionary sexual politics.

Marxist feminism has all too often fallen silent on sexual matters, and queer issues are sadly included in this. I recall attending a panel at Historical Materialism 2014 where trans feminist theorist Nat Raha was speaking on queer materialism and conceded that, at that point, little had been written. There remains a stubborn perception among many scholars that queer studies are supplementary, or perhaps antagonist in an anti-systemic methodological sense, to Marxist inquiry.

One issue is that the "realist" dimension of Marxism often results in gender analysis which begins by "securing the normative," i.e., working out why the "average" household exists as it does. This risks a downplaying of queer experiences as "exceptional," and a falling short of accounting for the impact we have had on various revolutionary movements.

AC: One person to blame is Michel Fou- 
cault. Or more precisely: the standard take on Foucault in gender and sexuality studies. There was a little early work on Foucault, such as Barry Smart's, that synthesized him with Marxism. But by-and-large, he is seen as an antiMarxist figure. In the Anglophone world, his anti-Marxism was played up. The Power/Knowledge collection begins with "On Popular Justice: A Discussion with Maoists," and History of Sexuality, Volume I begins with a critique of the Marxo-Freudian synthesis of Wilhelm Reich. True to form, a friend once recalled a queer theory seminar in which the class was offered the choice of reading the History "for the millionth time" or a work on Marx, and all of the people working in sexuality studies choose the former. Yet this opposition seems overplayed. operaismo long-incorporated his thought, and he remained essential to Gilles Deleuze and Félix Guattari's Marxist "universal history." And even when Foucault tussled with Marxism in the public spotlight, he remained partner with an unrepentant Marxist (Daniel Defert) and worked with the Prison Information Group to benefit communist prisoners. Though still a bit marginal, I think we are finally seeing a return with new translations of Guy Hocquenghem and Mario Mieli.

JJG: An increasing body of queer Marxist scholarship is already being written, however. First of all, I should mention the re- markable work of Georgy Mamedov and Oksana Shatalova, two queer activists based in the former USSR state of Kyrgyzstan. Their "Queer Communism Manifesto"14 and the more recent piece "Against Simple Answers: The Queer-Communist Theory of Evald Ilyenkov and Alexander Suvorov"15 both advance what they call the Queer Idea. The Queer Idea has a threefold character: "antiessentialism; a consideration of exclusion and stigma; and political and ethical radicalism." Following from this, their queer-communist politics is one of denaturalizing difference. Following Soviet philosopher Ilyenkov they promote the idea that the human is "100\% (not 99\%)" the result of social forces. This approach has informed their work at the school of Theory and Activism, Bishkek (STAB), during a time of increasing political homophobia in Kyrgyzstan. The queer-communist's response to the rightward shift of their political environment to a "complex question" is admirable, and their work is both rewarding and inspiring.

More conventional academic works include Kevin Floyd's Reification of Desire: Toward a Queer Marxism (2009), Peter Drucker's Warped:

\footnotetext{
14 Georgy Mamedov and Oksana Shatalova, "Queer Communism Manifesto," trans. by Mohira Suyarkulova, Art

Initiatives, November 29, 2013, WWw.art-initiatives.org/ $\mathrm{ru} / \mathrm{content/manifest-kvir-kommunizma-1.}$

15 Georgy Mamedov and Oksana Shatalova, "Against

Simple Answers: The Queer-Communist Theory of Evald

Ilyenkov and Alexander Suvorov," trans. by Giuliano

Vivaldi, ArtsEverywhere, August 17, 2017, WWw.

artseverywhere.ca/2017/08/17/against-simple-answers .
} 
Gay Normality and Queer Anti-Capitalism (2014), and Holly Lewis' The Politics of Everybody: Feminism, Queer Theory, and Marxism at the Intersection (2015), and each have taken somewhat different approaches to inaugurating research projects which are at once queer and Marxist.

Most clearly a defense of Marxism as a theory, Floyd convincingly makes the case for the totalizing drive of Marxism. Drucker's work is equal parts historical and theoretical and considers the non-normative gender formations which arise with an eye on the political economy that developed throughout successive eras. I found it especially helpful that Drucker included identities such as Elizabethan London's "moll" (effeminate men who often found work acting as female characters, or in "moll houses"). Lewis' work is a prolegomenon specifically to a queer Marxist feminism. The Politics of Everybody contains much valuable argumentation on topics ranging from deconstruction to trans politics which I had never encountered previously in a published academic work. Although I did not find her opening sections introducing the history of thought altogether reliable, Lewis succeeds in establishing a strong "point of departure" for a trans-inclusive Marxist feminism. These three books are powerful foundations for any number of queer materialist research projects.

JR: And to Jules' list, I would briefly add Petrus Liu's Queer Marxism in Two Chinas (2015). Liu's text being significant not simply in terms of the amount of research condensed in under 200 pages; Queer Marxism in Two Chinas shows how via Sedgwick's insight that rethinking sexuality can be a basis for rethinking the social, queer Marxism must be understood as neither the planned economy or collectivized labor of its historical counterparts. A true queer Marxism, as Liu puts it, is "a living philosophy" that brings Marxism to bear on queer lives; one that, before anything else, demonstrates that queer life is the content adequate to the methodology ${ }^{16}$ of Marxism.

AC: Yes, and I am often troubled by not knowing how to treat older socialist feminist works that attempt materialist analysis through gender essentialism. Consider, for instance, Shulamith Firestone's Dialectic of Sex: The Case for Feminist Revolution. ${ }^{17}$ on the one hand, it is rather popular today to relegate large parts of 1970's lesbian-separationist writing to the historical trash bin as anti-trans. While on the other, I am wondering if there are parts that should not simply be written off?

16 For the sake of clarification, the methodology intended here is neither dialectical materialism nor scientific socialism but rather historical materialism. And it is the historical materialist method of Marx that Liu views as the only legitimate means of thinking through what exactly a queer Marxism would and could be.

17 Shulamith Firestone, The Dialectic of Sex: The Case for Feminist Revolution (New York: William Morris and Company, 1970). 
JJG: The first trans-feminist I read was Lisa Millbank, the self-styled "RadTransFem." Millbank's hope was (and perhaps still is) to retrieve the insights of the second wave, including its thinkers who were most hostile towards trans women. I have since grown rather skeptical of her approach to performing "bandita" exegesis on radical feminist theory (which I think has failings which extend even beyond the transphobia Millbank tried to extricate them from: besides in the work of Andrea Dworkin, black women barely appear in this material.) And certainly I never found her guidebook (the self-published The Prude's Progress ${ }^{18}$ ) for stripping lesbian sexuality of all patriarchal domination altogether convincing. All the same, that was my introduction to transfeminism, although I had been reading radical feminist material for years beforehand. Like many trans women, I have also had a phase of intensively reading "TERF" (Trans-Exclusionary Radical Feminist) material. Above all, this taught me that transphobic feminism is a primarily middle-class phenomenon: the cladding of systemic thought is fit unconvincingly around the most base and everyday prejudice. You can see this most clearly in the gaping inconsistencies and "unlikely alliances" which proliferate in these circles (reactionary sexologists who believe

18 Available at the author's blog A Radical Transfeminist, 2012-2013, WWw. radtransfem.wordpress.com/category/ articles/the-prudes-progress. in innate gender differences are regularly embraced by TERF activists, for instance).

Many trans thinkers I know are in a state of exhaustion with regards to transphobic feminism. This year however I was pleased to read Joy Ladin's powerful essay "Diving into the Wreck: On Trans and Anti-Trans Feminism."19 Adrienne Rich was of course a central thinker in the second wave, and after Audre Lorde was perhaps its second-best poet. She was also a supporter of Janice Raymond, whose notorious screed The Transsexual Empire: The Making of the She-Male (1979) remains the definitive "TERF" magnum opus.

Rather than either dismissing Rich, or letting her off the hook, Ladin teases at how the figure of the androgyne appears fleetingly across Rich's own writings. Androgyny is at once prominent and awkward in Rich's oeuvre read as a whole: they slide in and out of view, oscillating from central to absent. In this way, Ladin executes exactly the method set out in the eponymous poem: delving into feminism's history and sifting free what transfeminism cannot afford to lose. This is "reparative reading," as Eve Sedgwick had it.

Question: Can there be a queer ethics? ought there be one?

\footnotetext{
19 Joy Ladin, "Diving into the Wreck: On Trans and Anti-Trans Feminism," Eoagh, Issue 9 (2017), wWw. eoagh.com/?p=2783.
} 
JJG: Ethics has become a focus for more and more theory. There are several major schools which provided a basis for thinking through how best to live. I will begin with Gilles Deleuze, as I know my interlocutors are experts on his work. Deleuze drew heavily from the writings of spinoza in his efforts to revitalize communist thought. Much of Spinoza's metaphysics was of course designed as a principle of "first principles" for his ethical thought. This "affirmationist" approach promoted by the extended influence of Spinoza's ethics is perhaps best expressed in a quote from Mark Fisher, now displayed on a mural at Goldsmiths College, London: "Emancipatory politics must always destroy the appearance of a 'natural order,' must reveal what is presented as necessary and inevitable to be a mere contingency, just as it must make what was previously deemed to be impossible seem attainable."20

JR: As I have mentioned to Jules in the past, clarifying this relationship between "ethics," Spinoza's Ethics, and Deleuze's interpretation of Spinoza's corpus is complicated for a host of historical and theoretical reasons (one particularly significant aspect of its complex history being the role of spinoza in the various attempts to de-Stalinize the French Communist Party, with Althusser being

${ }^{20}$ Originally from Mark Fisher, Capitalist Realism: Is There No Alternative? (Winchester: Zer@ Books, 2009), 16. perhaps the most notable). Given our roundtable format I will simply highlight a few features that I think are indispensable for understanding the logical and philosophical relationship that Spinoza and Deleuze maintain relative to that sub-discipline of academic philosophy we know as ethics, since it is their relationship to ethics itself that is a large part of Deleuze's recruitment of spinoza in his countertradition to the one that traces its roots back to eighteenth century European (Enlightenment) philosophy. It is only then that, I think, it is possible to determine what these various frameworks offer in terms of inquiring into the existence, possibility, desirability or moral obligation of a queer ethics.

For Spinoza, and more so Deleuze, ethics is not simply the search for an answer which adequately resolves the problem of how one goes about living the "good life"; in fact, the profound meaning of ethics remains irreducible to how individuals are more or less living a life of virtue even though the question of individual lives is a necessary part of any ethical project. So, in addition to concerns with living a life of virtue, ethics means an inquiry into the kind of relationship that needs to exist between our thinking, feeling and the ways in which particular social formations throughout history over-determine or condition a specific kind of relation between how we understand 
ourselves and how we understand who we are, and what we are capable of relative to the world as a whole. This definition of ethics (which clearly would not be accepted, or ever used, within academic philosophy departments) is one that views the question of an individual ethical life as one that inquire into how the problems, neuroses and blockages we confront and experience as personal, individual and private are, before being anything else, of a social, collective and therefore public nature. To détourn Deleuze's formula regarding the capitalist process of production: problems, dramas and crises are always social before being personal and individual. So any undertaking of ethics begins from the admission that not only do we retain various bad habits of thought that we use in daily life and that either produce half-formed concepts or unintelligible ideas; an inquiry into the socio-historical circumstances that favor the masses, the enslaved, the colonized or the proletariat to live in a condition where they find it easier to rely on the bad habits of thought and its mutilated concepts. Ethics, then, is the search for the truth of what it would actually mean to give detail and content to our present "condition"; a search that sees it necessary to discover the logical and necessary relationship between personal and social problems, between individual and collective neuroses. It is for these reasons that Spinoza can write, in the concluding Scholium to Part II, that his is a text written with the aim of aiding us in every aspect our lives:

in our social relations, in that it teaches us to hate no one, despise no one, ridicule no one, be angry with no one, envy no one [..] it teaches us that each should be content with what he has and should help his neighbor [..] solely from the guidance of reason as occasion and circumstance require [...] Finally, this doctrine is also of no small advantage to the commonwealth, in that it teaches the manner in which citizens should be governed and led; namely, not so as to be slaves, but so as to do freely what is best. ${ }^{21}$

AC: I should interject to say that there is a lot at stake with the varied uses of Spinoza in Marxist circles, namely, Louis Althusser and his students - Antonio Negri and Gilles Deleuze. Much is made of Althusser's turn to Spinoza as a rejoinder to Hegel and the dialectic. While this is true, the key insight lost to most is that Spinoza is introduced as an ally to Freud. Spinoza here provides the bridge between a theory of the subject and a

21 Baruch Spinoza, Ethics. Treatise on the Emendation of the Intellect, and Selected Letters, trans. by Samuel Shirley (Indianapolis, Indiana: Hackett, 1992), 100, EII P49 Scholium. 
larger materialist project. In contrast, $\mathrm{Ne}-$ gri sees spinoza as a joyous communist whose ethics are found in the collective - hence his preoccupation with imagining the figure of Spinoza's Multitude as it operates on different terms than Thomas Hobbes's imagination of the People. For Negri, it almost goes back to JeanPaul Sartre's earlier notion of the group-infusion. As such, Negri's reading contributes a political theory of Spinoza that undermines the Leninist paradigm of Marxist politics, from the need for a vanguard to the party's function in the discipline and education of the unformed masses. Deleuze's reading of spinoza is far less directed toward a specific political end. "The Ontological Turn" that included Speculative Realism, Actor-Network Theory, Assemblage Theory and New Materialism drew heavily on a reading of Deleuze's take on Spinoza, though for the most part, it was implicitly or explicitly anti-Marxist. My own favorite reading comes from Susan Ruddick, who argues that Deleuze and Guattari's Spinozism should be contrasted with Negri's; rather than providing us tools for building a collective, spinoza helps us disrupt the images of thought fed to us by tyrants and cheats.

All of these approaches provide wonderful tools for Marxism, but where in it does queer ethics appear? New Materialism seems to have taken up the challenge, as many of its thinkers came out of socialist feminism. Just look at the amazing career trajectory of Donna Haraway! The conceptual thread of kin and kinship continues to explore an important thread of queer thought. Remember, in the midst of Judith Butler's critique of Paris is Burning, she briefly praises how houses reveal alternative family structures.

JJG: As a pet gripe, Butler's treatment of Venus Xtravaganza in that essay is perhaps the weakest single passage in her career. She seems almost not to realize that xtravaganza is not a fictional character. It is a remarkably different approach to her painstaking phenomenological reconstruction of David Reimer's childhood in "Doing Justice to Someone."22

AC: Absolutely. As much as queer feminism wants to think about race, it largely treats it as a question of intersectionality, which combines the two through coalitional politics rather than a theoretical union. Most queer theorists still lack a theory of how race and gender intersect. Women's, gender and sexuality studies have only further sidestepped the issue a bit by turning toward "low theory."

New Materialism seems to offer a feminist alternative to low theory. But returning to "stuff" does not always sit well with Marxism

22 Judith Butler, "Doing Justice to Someone: Sex Reassignment and Allegories of Transsexuality," GLQ: A Journal of Lesbian and Gay Studies, Vol. 7, No. 4 (2001), 621-36. 
or queer theory, in spite of many theorists' best efforts. Training analysis on objects can easily slip into naïve commodity fetishism, and reversing the classic queer theory move of skipping past "being" to "doing" can turn into just another form of essentialism. Perhaps there are readings of spinoza that split the difference?

JR: I think Andrew is absolutely right. The turn to Spinoza by people of that generation is wholly political. Especially as it is no secret that Althusser himself saw Spinoza as the means of correcting the Hegelian perversions that were said to be the real causes of Stalinism. However, it is worth noting that given the fate of Spinoza as a figure to whom various political positions are assigned, the association of Spinoza and Deleuze with what is at stake not simply in queer theory but in queer life is due to a set of shared problems that are materialist in nature. Materialist because they are problems encountered within the concrete, actuality, of daily life. And while one might be tempted to consider Butler's remark as belonging to this materialist position insofar as these alternative family structures are concrete resolution to the problem of precarious housing situations, I would hesitate to endorse such a line of thinking. The solutions devised by already oppressed groups to the social problems generated by capital (housing, access to health care and services, etc.) are necessary and done out of survival. To put it bluntly: Butler's remark is nothing but the excitement of bourgeois voyeurism. If there is something particular to queer life that is depicted in Paris Is Burning it would be the conditions that determine what is possible and not possible as a queer (these conditions being the need for alternative housing structures, the fact of one's increased vulnerability simply by virtue of one's job, e.g., sex work, or gender identity, etc.). So, it is true that even the most refined theories of performativity fall short of addressing the material conditions of queer life. And just as both of you have noted, the key problem that arises out of the recent attempts in queer theory to overcome the limits of Butler's position are to be found in various positions that unwittingly make materialism into a variant of animism, or into a more one-sided account of the relationship between thinking and being where matter-itself is both problem and solution.

The latter of these two is best seen in Pheng Cheah's article "Non-Dialectical Materialism," 23 where cheah argues for a nondialectical theory of change by relocating the possibility of real social transformation in matter and not form, in the world of matter-it-

${ }^{23}$ Pheng Cheah, "Non-Dialectical Materialism," diacritics, Vol. 38, No. 1-2 (Spring-Summer 2008), 143-57. 
self and not the immaterial domain of idealism and its abstractions. While cheah argues that this is a position that is derived from Deleuze and Guattari's notion of impersonal forces and pre-individual singularities, it is not at all clear to me how these notions require a redefinition of the materialism that begins with Marx and continues in their joint works. It is true that Deleuze and Guattari are singular in thinking through the existence of supposedly absolute processes of deformation, or deterritorialization where what is at work is something that evades the classical distinctions between matter and its forms, or a form and its variable contents. But this is a theory about change in general, whereas the specific interest of transforming the material reality of queer lives finds no political guarantees in general theories of how change occurs in the world. So, what a non-dialectical materialism really amounts to is not a confirmation of Deleuze's many anti-Hegelian comments and rather amounts to neutralizing any possibility for a collective subject to change its material conditions and thereby transforming what the meaning and substance of their lives is in the process.

To detach any notion of revolutionary transformation from a materialism that begins from the concrete, reality, of queer life (and including its set of particular interests, desires, and needs) amounts to a vision of po- litical struggle that understands itself to be revolutionary due to the (over-)emphasis placed and privilege granted to the reality of change in general. This is tantamount to saying that what is most revolutionary in terms of change is a change that remains blind to the consequences for any subject or group whatsoever. It is a theory of change that is universal and equal only to the extent that we are barred from saying how and why it is beneficial for everyone... let alone for queers and especially queers of color. If what is at stake is not life in general but specifically queer, intersectional, life, then any notion of change can only be revolutionary to the extent that it is a qualitative transformation for queer life. And here we also encounter what is promising with the recent work on queer Marxism since what was revolutionary in the vision of communism is also at work in queer Marxism and in a historical materialist understanding of change. The kind of change we are interested in has never been general in nature; it is always for someone such as the proletariat of the past or the queers of the present.

JJG: "Bad habits" are of course a major contemporary trend in queer thought: nostalgia, effeteness, failure and other "negative affects" have been brought to the fore by thinkers like J. Halberstam, Heather Love and Sara Ahmed. What insights into this can be provided 
in assessing this trend by your queer Deleuzian ethical-politics? or do they suggest another direction?

AC: Recent queer feminist thought on bad feelings has really run the gambit. Lauren Berlant largely takes negativity as their state of being for relations, Sianne Ngai uses ugly feelings diagnostically, Heather Love returns to a history of injury to remind us of work left to do, and Jack Halberstam treats failure as pedagogical. As such, negativity is treated almost as the price for membership, in the queer community and otherwise. In contrast, Sara Ahmed's "feminist killjoy" is a positive project that lacks any redemptive qualities. I love how it has struck a chord with so many people.

Though not especially spinozist at first glance, one concept from Deleuze that has not really been explored in much depth comes from Anti-Oedipus. In it, he and Félix Guattari argue that subjectivity is retroactively produced through the excess of a social formation. (In the technical terms they use, the conjunctive synthesis of consummation/consumption is the process through which subjects "consume" what a socius produces and "consummate" their identity by claiming mastery over a particular body without organs.) As such, our identities are products we are meant to suffer/enjoy. This is why Deleuze and Guattari say that subjectivity is produced "like Prell shampoo," leading them to modify spinoza's famous axiom to be "god
= nature = industry." And as Nietzschean-Spinozist-Marxists, their position is certainly one of rebellion. ${ }^{24}$

What a different image of the subject than today's clichéd spinoza-talk of growing capacities, enhancing the subject, and larger collectives! When ripped out of Deleuze and Guattari's "universal history of capitalism" that includes various modes of subjectivity, such spinozism falls victim to a presentism that makes it indistinguishable from self-help maxims. Why all the metaphysical footwork if the end result is an "ethics" based on rather abstract notions of more, better, stronger? Here, the queer rejection of the naturalizing impulse to accept "what is" as a given remains absolutely key to maintaining our critical faculties. That is why I would be much more excited by a queer return to the historical materialism of Anti-Oedipus than another study of ethology or cosmic queerness.

JJG: My dear friend and performance studies scholar Jack Belloli has suggested queers should try focusing less on failure, and more on skills. I wonder if (and why) we find our failures a good deal easier to focus on...

JR: Perhaps the danger in focusing too much on failure as what defines queer subjects,

\footnotetext{
${ }^{24}$ Gilles Deleuze and Félix Guattari, Anti-Oedipus: Capitalism and Schizophrenia, trans. by Robert Hurley, Mark Seem and Helen R. Lane (Minneapolis, Minnesota: University of Minnesota Press, 1977), 254-5.
} 
and a danger that I think you are rightly critical of, is that it equates what queers make of their own identity with the material conditions and limits that define their subject-position within capital. And it is for this reason that the features of antagonism, abolition and so on are so important since every identity that simply assumes a ready-made position within capital is one that readily identifies with everything that maintains their precarity, alienation and dispossession. However, I will say I am inclined to say that what Halberstam gets right in theorizing failure as a queer art is the idea that failure is indicative of the degrees of separation between oneself and the norms that give order to and render intelligible one's social existence. Failure, however, is not a program and particularly for queers it is something that can even be worse than death. And to quickly return to Andrew's point (and one that $I$ am in agreement with) regarding the possibility of arguing for a queer subjectivity in Anti-Oedipus: this queer anti-Oedipal subject is one that is defined by its antagonism and combat, and not its reliance on the "failing better" because we were never in a position to afford failure in the first place. So, it is for these reasons (and more!) that the ethical tradition coming out of Spinoza and Deleuze concludes that if we are made to undergo sadness, to feel weak, to be made to see lies as truths, eliminating the cause of our anguish means nothing short of eliminating the society in which one finds themselves. Or in the words of Anti-Oedipus: "The Women's Liberation movements are correct in saying: We are not castrated, so you get fucked."25 And in spite of Sara Ahmed's critical take on Deleuze's theory of affects, what is common to the models of subjectivity that come out of Ahmed's killjoy, Deleuze and Guattari's schizo-subject, is their unruly character, their subjectivity being one that is willful. This is a subject that does not simply "fail" to re-calibrate its desire to the demands of capital, it is a subject of non-compromise, one that refuses to collaborate with the forces that seek out its repression.

To conclude and bring together my earlier comments, I think two things can now be clarified: First, if there exists something like a queer ethics, it is an ethics insofar as it is critical of, and materially organizes against, the present state of things (abolition thesis). Second, this definition of ethics echoes various definitions of queer and queer subjectivity, such as Lee Edelman's No Future; or the queer subject found in works like Queer Ultraviolence (a text that I know all three of us have a deep affinity for!) and related groups such as Bash Back!. These would belong to a definition of queer ethics as the project of finding the means

${ }^{25}$ Deleuze and Guattari, Anti-Oedipus, 81. 
to reverse engineer capital's death-drive that governs one half of social life. It is an ethics of un-doing; or, as Andrew puts it in his book on Deleuze, it is the labor of un-becoming all the internalized guilt, self-hatred, and resentment of this world in order to better work toward its abolition. Additionally, queer subjects undo what has been done to them, so they can relieve themselves of the burden to be, or to fail at being, somebody. And perhaps this refusal of being somebody is what Deleuze and Guattari mean when they talk about the joy of being nobody, of becoming-imperceptible:

To become imperceptible oneself, to have dismantled love in order to become capable of loving. To have dismantled one's self in order finally to be alone and meet the true double at the other end of the like. A clandestine passenger on a motionless voyage. To become like everybody else [..] to no longer be anybody. ${ }^{26}$

JJG: Probably my favorite piece in the Back Back! reader is titled "What Is it to Become Beautiful?" It argues that ugliness leaves you along with liberalism, as you immerse yourself in the collective process of overcoming oppression. In contrast to much of the radical

${ }^{26}$ Gilles Deleuze and Félix Guattari, A Thousand Plateaus, trans. by Brian Massumi (Minneapolis, Minnesota:

University of Minnesota Press, 1987), 197. feminist material I have already mentioned, it explains: "Becoming beautiful means fighting a liberatory struggle without a utopian illusion of liberation."27 This speaks to my experience with queer politics, and friendships.

JR: Same! And I have always thought that, in some way, "What Is it to Become Beautiful?" is a necessary companion piece to Tiqqun's Preliminary Materials for a Theory of the YoungGirl, and particularly with respect to the chapter on the young-girl and anorexia. ${ }^{28}$ Here, the young-girl, discovering there is little she can do to change the world around her, embarks on the task of changing herself. The painful outcome of this being that the young-girl finds herself in a situation of powerlessness only to transform it into a mastery over herself and body. So given the severity of life as a young-girl, "What Is it to Become Beautiful?" is a necessary rejoinder in that it rejects beauty as the self-subjugation of younggirls for beauty understood as "the violent and persistent confrontation between your body and Cosmo"; and where the violent and relentless confrontation definitive of this kind of

\footnotetext{
27 The Mary Nardini Gang and A Gang of Criminal Queers, "What Is it to Become Beautiful?," in Queer Ultra Violence, ed. by Fray Baroque and Tegan Eanelli (California: Ardent Press, 2011), 278-82.

28 See Chapter 9 "The Young-Girl against Herself" in Tiqqun, Preliminary Materials for a Theory of the YoungGirl, trans. by Ariana Reines (Los Angeles, California: Semiotext(e), 2012), 121-30.
} 
beauty is also "the youth's only hope."29 But putting aside what is produced by "theory" we can also take our cue from history, and particularly from Stryker's Transgender History where we read the stories of what went down at the Cooper's Donuts in Los Angeles (1959) and Dewey's Lunch Counter in Philadelphia (1965) ${ }^{30}$ since these were moments where solidarity between sex workers, homeless youth and the surrounding working-class neighbors meant defending each other's lives against the economic and political violence of the state. And so those present at either Cooper's Donuts or Dewey's Lunch Counter can equally serve as models of the ethically queer life. This also has the added benefit of serving as a qualitatively different vision to Butler's remark, which Andrew pointed us to. In any case, and given the fact that most of this engagement with the ethics of queer life comes from those projects influenced by Spinoza, Deleuze and Guattari, Althusser, etc., I wonder what other approaches to ethical life can help queers?

JJG: I would like to introduce two other trends relevant to the discussion: firstly, eth-

${ }^{29}$ Gang and Queers, "What Is it to Become Beautiful?," 282.

30 Susan Stryker nicely summarizes the history, relation, and significance of these two dates as follows: "The Dewey's incident, like the one at Cooper's, demonstrates the overlap between gay and transgender activism in the working-class districts of major U.S. cities in spite of tensions and prejudices within both groups." For more see Susan Stryker, Transgender History (California: Seal Press, 2008), 62 . ics approaches as a form-of-life, and secondly, the revival of Aristotle's "Virtue Ethics" performed by Alasdair MacIntyre.

"Forms of life" has proven a recurring phrase in ethics since the twentieth century, although the term has a slightly tangled history. A similar turn of phrase appears in Michel Foucault's famous essay "Friendship as a way of Life," 31 but the term forms-of-life in fact originates with Ludwig Wittgenstein (usually a figure associated with "analytic philosophy"). Wittgenstein began his Philosophical Investigations with an engagement with St. Augustine's view of the image, indicating his shift away from an earlier style of philosophy as propositional treatise (which had become a central text to the canon of logical positivism, due to the Vienna Circle's unrequited fascination with Wittgenstein's Tractatus).

In the Philosophical Investigations, wittgenstein argues that language operates not primarily according to incorrect or correct statements, but instead as a series of games which can only be understood through grasping the whole relevant culture. In this way, some kind of collapse between semantics and ethics occurs. (The exact implications of this have seen wildly diverging interpretations).

\footnotetext{
31 An interview with the French publication Gai Pied that appeared in 1981, published in an English translation by John Johnston in Michel Foucault, Ethics: Subjectivity and Truth, ed. by Paul Rabinow (New York: The New Press, 1997), 135-40.
} 
Forms-of-life was then adopted in the 1950s by Pierre Hadot. ${ }^{32}$ Hadot was among the first French scholars to engage with wittgenstein, a shift from his earlier career as a scholar focused on ancient and medieval thinkers (especially Plotinus). These two interests were brought together as follows: Hadot argued that, rather than providing an attempt at systematic thought proceeding through defensible propositions, ancient philosophy instead served as a means towards living a philosophical life. Rather than systematic treatises expected to be read as progressive successions of propositions, philosophical writing was intended to challenge and train its reader.

Hadot's thought was deeply influential on Michel Foucault, who drew much of his approach toward Late Antiquity's thought from Hadot's writings (as explored in Stuart Elden's Foucault's Last Decade $\left.{ }^{33}\right)$. Foucault's key ideas concerning "care of the self" were based on reading ancient philosophy as ethical aids (or technologies, as Foucault, but not Hadot, would term them). In understanding Foucault's approach to "normativity," this ethical undergirding needs to be considered.

\footnotetext{
32 An English translation of this is available: Pierre Hadot, "Forms of Life and Forms of Discourse in Ancient Philosophy," trans. by Arnold I. Davidson and Paula Wissing, Critical Inquiry, Vol. 16, No. 3 (1990), 483505 .

33 Stuart Elden, Foucault's Last Decade (Cambridge: Polity, 2016).
}

Giorgio Agamben drew then on the phrase forms-of-life in his 2013 monograph The Highest Poverty, which analyzed the normative writings used by medieval monastic founders. Normative writing was used in medieval monasteries to establish the explicit limits of communal formsof-life (Agamben's focus is mostly on western material, the regula et vita, while my own is focused on Byzantine typika). Most interestingly, Agamben treats the development of this type of writing as a genre question. I think that kind of approach might prove more widely applicable as we attempt queer cultural inquiry. Alasdair MacIntyre's After Virtue (1981) ${ }^{34}$ provides another view of the history of morality. MacIntyre notes that moral issues of the day (which often appeared as points of political discussion) were "incommensurable," beginning from such differing principles that resolution could never be achieved. Yet besides vague references to differing "value," moral philosophy did not seem to provide any warnings of this. MacIntyre charged moral philosophy as suffering from a state of continual overproduction: imperatives of securing employment ensured a churn of publications which could never hope to further moral inquiry in a meaningful sense (instead serving solely as professional ephemera fit for feathering careerist nests). In

${ }^{34}$ Alasdair MacIntyre, After Virtue: A Study in Moral Theory (Notre Dame, Indiana: University of Notre Dame Press, 1981). 
other words, MacIntyre provides a materialist thumbnail sketch for the intellectual bankruptcy of contemporary professional philosophy.

Instead of perpetuating this, MacIntyre proposed a return to the ethical maxims of Aristotle, for whom virtues were displayed amongst one's peers. (MacIntyre compares these plural "virtues" with the singular "virtue" Christians sought to protect during modernity: morality as reducible to avoiding or performing particular deeds). In this way, MacIntyre provides an approach to ethics which centers the community, the group of mutually concerned peers. Ethical life arises not from contemplation, nor revealed truths, but from reciprocal conference.

Both of these approaches to ethics stress their core as relational, and habitual. Virtues and forms-of-life are both responsive to historical activity and cannot be understood without appreciating the contours left by it. Both these views can serve as aides in our efforts to (collectively) achieve queer survival. But they also show us what it truly means to make up your own language, to set your own terms, to choose your own friends. They show us that queer community is not an end but our means toward ethical ordering (even in our unfavorable circumstances, or especially).

To me, both of these approaches have much greater merit than is widely realized. Foucault is (of course) a towering figure in queer thought, but it is disappointing that the pro- found reach, and deep roots, of forms-of-life is not more widely known. If we are to provide a challenge to the heterosexual normative order, appreciating the depth of Wittgenstein and Hadot's attack on "proposition-centrism" is one way of doing that.

AC: "Life" itself has followed quite an itinerant line. Vitalist philosophies have grown in popularity as Henri Bergson has been thrown back in the spotlight. Yet there are older vitalisms that remain integral to how we think about social and political life, perhaps the most important being Afro-Caribbean Thought. Parenthetically, Donna V. Jones's investigation in The Racial Discourses of Life Philosophy ${ }^{35}$ is essential here.

I am curious how queerness problematizes "life." Queers have long been accused of being anti-life, something etched deeply into the gay unconscious through the AIDS crisis. Lee Edelman's polemical treatment of reproductive futurity is one response: when Focus on the Family accuses queerness of being the end of the world, let us meet their bet and raise them one. This is the queer nihilist politics of the journal Baeden and other that I have a strong affinity towards. There is even one way of reading Foucault's final chapter of History of Sexuality, Volume 1 as warning about all of the dangers

35 Donna V. Jones, The Racial Discourses of Life Philosophy: Négritude, Vitalism, and Modernity (New York: Columbia University Press, 2011). 
associated with using life as a category of thought in the age of biopolitics. Yet with all of these risks, queerness is driven to explore otherness on its own terms; forging alternative intimacies, locating new spaces of encounter, cultivating weird archives.

My own approach has been to take the easy way out. In Dark Deleuze, I use the discourse of gay shame when dealing with subjectivity. ${ }^{36}$ This fits with a move in contemporary theory toward pessimism, perhaps the most well-known being Afro-pessimism. As argued in a recent article Jose and I helped publish, ${ }^{37}$ the result is a "negative identity politics" whereby we fight from the subject position we inhabit but through a disidentification from ourselves. Though I should admit that when writing Dark Deleuze, I had not yet worked out how Afropessimism could fit with my approach to Deleuze, especially given how extensively Frank B. Wilderson, III draws on Lacan. As a placeholder, I reiterated Deleuze's use of George Jackson as the paradigmatic figure of a line of flight. It took me a long time to work it out, but I recently completed the manuscript for an essay on the coincidence of Afro-pessimism and the Non-philosophy of François Laruelle. Look-

\footnotetext{
36 Andrew Culp, Dark Deleuze (Minneapolis, Minnesota: University of Minnesota Press, 2016).

37 K. Aarons, "No Selves to Abolish: Afropessimism, Anti-Politics, and the End of the World," Hostis, Issue 2: Beyond Recognition (2015), 103-27.
}

ing at the big picture, my argument is not that all of these pessimisms put us all on the same team. Though for us, even if their starting points are radically different, we see comparative theories of self-abolition that indicate to us that queerness, left communist anti-politics, and black thought all drawing from a similar playbook.

JR: Perhaps the most striking difference between the ethics of Deleuze/Spinoza and that of "forms-of-life" is that while we have found some way of providing some content to the concept of the ethical existence of queers (un-doing, antagonism, ultraviolence, etc.), the same cannot be said for the latter. This is made even more difficult since the form that mediates and binds a life to itself, at least with respect to its use by Agamben, is any form whatsoever. The only requirement being that it accomplishes this fusion of norm and life. In the case of Wittgenstein, this concept does seem to gain further utility for the question of ethical practices for the realities of queer life - what good is a form-of-life if it simply signifies everything that grounds the possibility of utterances (environment, culture, history, politics, etc.) to be received as meaningful by a linguistic community? Moreover, what happens if the forms-of-life that ensure meaningful communication harbor within themselves the norms and values against which queers rebel? 
What good is the guarantee of meaning when the meaning and worth of life is unequally and unevenly distributed across the globe? Asked in this manner, one is tempted to say that it is because this lineage, which starts by privileging the guarantee of meaningful speech in our socio-linguistic environment in order to understand forms-of-life, that it also ignores ways in which queers have been, and continue to be, those who signify an aberration or who are consigned to a life defined by their slow and/ or social death.

In the face of these theoretical blind spots, perhaps it is better to say that what is specific to queer subjectivity with all its antagonism and violence is precisely that it begins not from some transcendental grounding of meaning but from meaninglessness as both an objective condition as well as a subjective tendency. This approach also imagines the subjects of un-doing or self-abolition as a life that introduces deviant, meaningless, a-signifying utterances. Instead of staving off the complete loss of meaning, queer subjects find their home in the non-signifying breaks of language since it is only in the moments when the foundations of meaningful speech are felt to be in question that there comes into existence the possibility of "producing a new utterance, an operation of the signifier as expression of a meaning, a possible split in a given order, a breach, a revo- lution, a cry for radical reorientation."38 The more auspicious moments for the ethically queer subject, then, are more likely to be those situations where the very meaning of speech itself is no longer guaranteed and called into question (and perhaps this is part of why you, Andrew, mentioned Baeden). Or better still, in addition to the suspension/contestation of hegemonic structures and its meaning, ethically queer subjectivity gains in force when it confronts those structures without betraying the fact that the meaning of its life and its speech remain incommensurable with the semiotic systems required by capital. Now, on this topic of imagining a form of revolutionary subjectivity that is equally communist and queer, perhaps we encounter another, related, question regarding queerness and what Jules once called a "communitarian ethic": namely, can queer politics ever overcome the communitarian framing, and does it even need to?

AC: Miranda Joseph's Against the Romance of Community is the key reference for me. ${ }^{39}$ In it, she argues that communities are constituted through practices of production and consumption. This is where the queer critique of homonormativity is really enhanced by a Marxist

38 Félix Guattari, "Causality, Subjectivity and History," in Psychoanalysis and Transversality. Texts and Interviews 1955-1971, trans. by Ames Hodges (Los Angeles, California: Semiotext(e), 2015), 235-80, 239.

39 Miranda Joseph, Against the Romance of Community

(Minneapolis, Minnestota: University of Minnesota Press, 2002). 
perspective. of course, there is also the sociological problem of community as being constituted through a clear inside-outside, that almost-always lead to boundary policing like at MichFest (Michigan Womyn's Music Festival) - an internationally-influential annual womenonly gathering of feminists that ran from 1976 until 2015, when organizers decided to shut it down rather than include transgender women.

JJG: MacIntyre's challenge to modern moral philosophy has proven widely influential, but so far as I know has limited traction in queer thought. This is a pity, and I think many of the "surface level" discussions which clutter queer life (call outs, etc.) could be grasped better with Aristotelian conceptions of virtues in mind. My view is that many of the more ferocious disputes between queers are unwitting efforts to resolve questions along these lines, in a hostile context. They are efforts to work out who our peers are, before it is too late.

Using this lens, you can answer quite easily why, for instance, the 1980s row around S\&M became so intractable during the events around the Barnard Conference. The exchange was between loose groups with markedly differing mores and conventions: the leather dykes drew from gay S\&M counter-culture and participated in mixed gender spaces, which developed a great number of the conventions around consent and sexual safety still in use to this day. Anti-
S\&M lesbians were more firmly rooted in consciousness raising circles and tended towards a lesbian separatism that deemed even Andrea Dworkin impure, due to her bisexuality. ${ }^{40}$ For these groups lesbianism specifically was not a quality of revolutionaries, but was the revolution. (The most succinct and abstract defense of this position is found in the writings of Monique Wittig). At its worst, this stance proposed lesbianism as something to be protected (from gay men, bisexual women, and the male energies of S\&M freaks.) The divergence in "operative context" of each party meant much of this debate occurred around incommensurable po-

40 Dworkin describes attending an event called "Lesbianism as a Personal Politic" in 1977: "Hisses. Women shouting at me: slut, bisexual, she fucks men. And before I had spoken, I had been trembling, more afraid to speak than I had ever been. And, in a room of 200 sister lesbians, as angry as I have ever been. 'Are you a bisexual?,' some woman screamed over the pandemonium, the hisses and shouts merging into a raging noise. 'I'm a Jew,' I answered; then, a pause, 'and a lesbian, and a woman.' And a coward. Jew was enough. In that room, Jew was what mattered. In that room, to answer the question 'Do you still fuck men?' with a No, as I did, was to betray my deepest convictions. All of my life, I have hated the proscribers, those who enforce sexual conformity. In answering, I had given in to the inquisitors, and I felt ashamed. It humiliated me to see myself then: one who resists the enforcers out there with militancy, but gives in without resistance to the enforcers among us." Originally published as: Andrea Dworkin, "Biological Superiority: The World's Most Dangerous and Deadly Idea," Heresies No. 6 on Women and Violence, Vol. 2, No. 2 (Summer 1978), 46-9; reprinted in Letters from a War Zone. Writings 1976-1986 (New York: E.P. Dutton, 1989), and accessible online at Andrea Dworkin Online Library, no date, WWW.nostatusquo.com/ACLU/dworkin/ WarZoneChaptIIID. html. 
sitions, despite superficial commonalities such as an overrepresentation of humanities academics, and both sides facing down stigmatization from much of the public. It is for this reason that no fruitful resolution occurred (most participants have not changed their basic stances, but simply no longer want to talk about the dispute) .

I should clarify that my view is not a pessimistic one: although sometimes fractious to the point of fractal, queer communities have done remarkably well at protecting and defining themselves, and at providing places of refuge for those left in dire need by the heterosexual order. One example of this is the success (despite the odds) of ACT-UP in saving untold millions of lives from the AIDS crisis. In the early years of the epidemic, ACT-UP not only agitated for further funding, but in fact compiled and processed huge reams of information $A$ range of queer groups used this knowledge and developed the original "safe sex" (later fully co-opted by the global state/NGO complex). Even by 1987 this process was well underway, as recorded in Douglas Crimp's remarkable essay "How to Have Promiscuity in an Epidemic."41

${ }^{41}$ Crimp notes the conceptual limits in understanding AIDS that were to become yet more prominent a decade later, with the introduction of retrovirals: by the late 1980s, AIDS was a crisis which mostly killed Africans. After the introduction of retrovirals this became a yet sharper divide, and black communities in the United States were often left without access to treatment due
Many of those who dedicated their time to this process were trained medical professionals, but the bulk were considerably less qualified than the many medical experts who did nothing to end the crisis in its early years. "Making do" is often the order of the day, queer survival skills are often picked up as required. Necessarily, survival in times of crisis demands of us mastery of skills in which we have often not received formal training. Instead, queer survival is enabled through queer communities.

To talk of "community" in queer circles is to invite cynical responses ( $I$ think few of us have not been burnt badly in one way or another from within anti-heteronormative spaces), but some theorization of communities is simply inevitable. We do not have the luxury of a truly mass culture. Instead, throughout queer history specific territories, conventions, counter-cultures, aesthetics and mores have arisen and shifted rapidly, often baffling and horrifying outsiders. We teeter constantly between the esoteric, the arbitrary and the class collaborationist. MacIntyre and "forms of life" theorists each gesture towards the bedrock of moral inquiry within social relationality. Towards the norms we agree upon in opposition to the prevailing normativity.

to profit-driven healthcare. Douglas Crimp, "How to Have Promiscuity in an Epidemic," October, Vol. 43 (1987), $237-71$. 
JR: I think the last point you made about the connotations of the word "community" in queer circles is something that most, if not all, of my friends and I have been feeling for quite some time. And, of course, this is tricky since we need each other, and yet queer communities still fall prey to the exclusion, marginalization or erasure of other queers. In this instance I am sympathetic to the use of "formof-life" as a way to understand what theorizing about queer communities would mean; since at the very least it would require us to provide the determinate content of what is both desirable and detrimental in terms of a queer formof-life. And perhaps when we end up specifying just what is queer about this form-of-life, we discover that it has something to do with this issue of, as you pointed out, thinking the relation between a community and its survival. Moreover, the form-of-life as a way of theorizing this relation could lead us to a position that treats phenomena such as resisting arrest, fighting back against police violence and defending the spaces that give queers access to material resources, and can no longer be treated as a moral dilemma up for public debate (such as the one we are seeing today regarding whether or not anti-fascist groups in the U.S. are in fact the same as the neo-Nazis and white supremacists they oppose): these are simply the skills and knowledges needed to protect queer lives. But what is the ultimate outcome of all this? More militancy without material stability and/or gain? Not quite. And since I could not put it in anymore beautiful and precise terms, I will simply repeat what transpinay/bakla author b.binaohan writes in the introduction to her Decolonizing Trans/Gender 101:

The community and available resources are critical for ensuring that more of us lead successful lives in ways healthy and happy. To allowing many of us to survive. And for us to go beyond survival. To reach a place where we can be free. of oppression, of violence, of racism, of cissexism, of transmisogyny, of transphobia, of colonialism. Just. Free. ${ }^{42}$

It should be noted that b.binaohan's work on the intersection of race and gender is additionally important here since she begins her analysis by addressing the way in which gender, like class, is racially constructed. And I think it is true that any theorization on community relative to queer subjects needs to confront and find ways of addressing the continued effects of colonialism and race as they manifest themselves in queer spaces. Failure on our part to do this intellectual and prac-

42 b.binaohan, Decolonizing Trans/Gender 101 (biyuti publishing, 2014), 6-7. 
tical labor within queer spaces has the potential consequence of excluding, tokenizing and/or outright erasing of the experiences and conditions of queers of color, and particularly I am thinking of indigenous and/or trans women of color. It would mean that despite our good intentions there remains the possibility of repeating exclusion and/or co-optation in the very construction of this form-of-life the clearest case of this being Sylvia Rivera's ousting from the Gay Liberation Front (GLF):

... Sylvia Rivera (and other trans women of color) who were pushed out of the Gay Liberation Front by white gays as a means to divorce themselves from the disreputable "trans women" for a bid of respectability politics. Of course, it worked, given that the GLF was able to obtain some sort of civil recognition while entirely omitting the needs of trans women from it. ${ }^{43}$

JJG: I was recently re-watching Rivera's famous "Y'all Better Quieten Down" speech at the Christopher Street March in 1973 (received much more favorably by history than it was by gays and lesbians at the time). I was always struck by the precision of her arguments: that her rapists in prison had been straight men. But what I had not fully recognized in my ear-

43 b.binaohan, Decolonizing, 69. lier viewings was how this was very much an organizational intervention: she gives the address of S.T.A.R. (Street Transvestite Action Revolutionaries) and encourages the crowd to come along. It is no howl of anguish, but even in the face of audience hostility, an attempt to forge a group fit to confront the dire conditions of 1970s trans street life. Her thinking and activity were both oriented towards solidarity and political formation. We need to recover that spirit.

Question: What challenge does queerness pose to distinctions between species? Must (or can) queers be human? Does developing queerness demand of us a new humanism, anti-humanism, or both?

JJG: Questions around humanism are becoming a raging concern for queer studies, while having already burnt themselves out in various other fields. With the trenchant Afro-pessimist Lacanian attacks of Calvin warren on much of queer studies for what he calls its "closeted humanism," 44 this controversy seems set to continue. (For what it is worth, I do not agree

${ }^{44}$ See Calvin L. Warren, Onticide: Afropessimism, Queer Theory, and Ethics (ill will editions, 2015), 8, 21, WWW. illwilleditions . noblogs . org/files/2015/09/War ren-OnticideAfropessimism-Queer-Theory-and-Ethics-READ.pdf; Calvin L. Warren, "Onticide: Afro-pessimism, Gay Nigger \#1, and Surplus Violence," GLQ: A Journal of Lesbian and Gay Studies, Vol. 23, No. 3 (2017), 391-418. 
with Warren that much of queer theory is humanist, but I personally am happy to come out of the closet as one.)

These questions are entwined with the limits of species, another normative boundary most see as foundational to life, but which some queer scholars have done their best to trouble.

It is safe to say that animals loom large in both queer activist politics and thought and are especially prone to testing the conventional limits of inter-species concern. Veganism is a wholly disproportionate practice among queer circles as compared to the "general population." (For their part, meat eaters and hunters are often prone to framing their practices as "manly," or "red blooded.")

Queer animals have become a flourishing concern for some gender theorists. In many cases, this focus corresponds to a rejection of humanism. One strand of "methodological antihumanism" which has proven especially fruitful, if quite strange to the uninitiated, is actor-network theory. The often exuberant, often cryptic, work of Bruno Latour has found much favor throughout the culturally-oriented wings of the humanities. This school was drawn into dialogue with Marxism feminism by Donna Haraway, in her classic cyborg Manifesto. Haraway saw overcoming species boundaries as only one frontier in the contemporary's collapsing of dichotomies: "The dichotomies between mind and body, animal and human, organism and machine, public and private, nature and culture, men and women, primitive and civilized are all in question ... they have been 'techno-digested.'"45

Much of queer treatment of animals is informed by this approach, seeking to overcome the more obvious points of focus for scholars. But recently this decentering of the human has come under fire. Andrew has already mentioned that Haraway's career has taken some... unlikely... turns. A recent piece by Sophie Lewis, "Cthulhu Plays No Role for Me," 46 challenges the drift of Donna Haraway's thought into a misanthropic anti-natalism, which (despite $\mathrm{Ha}-$ raway's protests and disclaimers) cannot escape racism. I side with Lewis' thoughtful and personally engaged critique: we should be cautious that anti-humanism is not treated as a "quick fix" in avoiding a nativism and anti-blackness, that is actually much more pervasive than a mere corruption produced by humanist thought. Racist thinker Nick Land's "Accelerationism" also shows this: anti-blackness and anti-humanism can be perfectly compatible. ${ }^{47}$ And Eve

45 Donna Haraway, "A Cyborg Manifesto: Science, Technology, and Socialist-Feminism in the Late Twentieth Century," in Simians, Cyborgs and Women: The Reinvention of Nature (London and New York: Routledge, 1991), 149-81. 46 Sophie Lewis, "Cthulhu Plays No Role for Me," Viewpoint Magazine, May 8, 2017, WWw.viewpointmag.com/2017/05/08/ cthulhu-plays-no-role-for-me.

47 Simon Reynolds, "RENEGADE ACADEMIA: The Cybernetic Culture Research Unit," Energy Flash, November 3, 2009, 
Mitchell's masterful essay "I Am a Woman and a Human" shows that black feminism and what she calls "Fanonian humanism" are equally compatible. ${ }^{48}$

Anti-humanism and humanism are each prone toward supporting anti-blackness, crude "triumph of civilization" teleologies, and species chauvinism; in that each of them arises from a shared social context. The ferocity of recent anti-humanist offensives within queer studies conceal how low the stakes are, when the battleground is primarily outposts in academia. Rejecting this or that school of thought will never serve as a cast iron guarantee that we are not reproducing the worst in the world. We should be wary of scholarly fads, as vital as they are to contemporary academic careers. Only the dialectic can be trusted: not to deliver us from any evil, but as a means of us delivering one another.

AC: I tend to shy away from naturalistic examples in my writing. Though lately

WWW . energyflashbysimonreynolds . blogspot . co . at/2009/11/ renegade-academia-cybernetic-culture.html; Robin Mackay, "Nick Land - An Experiment in Inhumanism," Umělec Magazine, No. 1 (2012), WWw.divus.cc/london/en/article/ nick-land-ein-experiment-im-inhumanismus; Jeremy Gilbert, "My Friend Mark," Jeremy Gilbert, March 2017, WWw. jeremygilbertwriting . files . wordpress . com/2017/03/myfriend-mark40.pdf.

48 Eve Mitchell, "I Am a Woman and a Human: A Marxist Feminist Critique of Intersectionality Theory," LibCom, September 12, 2013, wWw.libcom.org/library/i-am-womanhuman-marxist-feminist-critique-intersectionality-theoryeve-mitchell.
I have been trying to expand out the intellectual history of western epistemologies of the human started by Foucault in The order of Things. While Foucault ends the book on the Death of the Human, much like Nietzsche's Death of God - opening the door to animal studies - I think that the episteme that followed it was planetary-thinking. Yet we are seeing an exhaustion of this thinking, especially with the crisis-level failure of planetary and human sciences to properly address the environmental devastation wrecked by humans throughout the Anthropocene.

Returning to the human, I have been thinking a lot about two categories: monsters and aliens. There is a long tradition of thinking sexuality through the monstrous, in large part due to a monster's disfigurement serving as a metaphor for the bodily dimension of abjection. So, in contemporary theory, there is christina Sharpe's Monstrous Intimacies and Susan Stryker's essay in The Trans Studies Reader on Frankenstein. ${ }^{49}$ Yet I think that there is a limitation to using monsters to think about the human: it treats marked subjects as deformations of the human. And while that might be a

49 Christina Sharpe, Monstrous Intimacies: Making PostSlavery Subjects (Durham, North Carolina: Duke University Press, 2010); Susan Stryker, “My Words to Victor Frankenstein above the Village of Chamounix: Performing Transgender Rage," in The Transgender Studies Reader, Vol. 1, ed. by Susan Stryker and Stephen Whittle (London and New York: Routledge, 2006), 244-56. 
useful index of how popular discourses might treat subjects, its deconstruction exists within a limited political horizon. The two poles: forced inclusion and voluntary exclusion. The demand for no longer being treated as in-human, or the choice to fight the system from the outside.

The alien seems more interesting to me. Unlike the monster, which is the familiar that has become strange, the alien is something truly other. Certainly, there is an established phenomenology of the other, such as Lacan's model whereby "desire is the desire of the other," "the unconscious is the discourse of the other," and "there is no other of the other." Yet those approaches always return to scenes of recognition, which causes the same deconstructive re-inscription problem I mentioned when discussing the monstrous. I do not mean using the alien to once again deconstruct the human by revealing an outside that appears as a supplement but is necessary for constituting the very boundaries of the category of the human itself. Instead, what about that even more dissident tradition of thinking the outside on its own terms? That of Blanchot? This is where Edelman places queerness. For him, queerness is not an identity that one embodies, not even partially or temporarily. Queerness jams the gears of the symbolic. It is the alienating force of the libido that wildly disrupts any attempt to identify whatever. It is the birds themselves in Hitchcock's The Birds. So in this sense, becoming-animal would neither include barking like a dog or galloping like a horse nor even undergoing a personal transformation through a relationality with animals. It would mean a radical break from the human altogether, not on a personal level, but as the outside force of the great unknown comes crashing down on all of us at once.

JR: It seems that the relationship of queerness to humanism and to species (if there is one at all) presents a variety of possibilities but none of which seem to present themselves as either unavoidable or necessary. Primarily due to the ambiguity of the term species here, since one might think that discussions of species regarding humanism are referencing Marx's notion of Gattungswesen (species-being) and whose meaning is determined in political and historical terms rather than those of evolutionary biology, for example. If the question refers to determining who does and does not count as "human" within a humanism, and we understand humanism to be a social and political project and not some taxonomy of differing bodies, then at the very least we could say that queers have been excluded from enjoying all the privileges granted to fully human subjects. So here the question of species understood as a product of the development of life on this 
planet has little purchase on the discussion.

Alternatively, if we understand species in its evolutionary biological sense, the recent work of Preciado comes to mind. Mostly because Testo Junkie is a text that is less ethical philosophy than a historical, material and political attempt to update various theories of how power and capital are related (and whether it be Foucault's biopolitical regimes or Deleuze's control societies). Additionally, it is a text whose main argument is that humans as a species have now become capable of determining a large portion of their own evolution as a species; and this is clearest seen in the production of hormones like testosterone or the ubiquity of the pornographic image. Therefore, Preciado concludes that what is fundamentally at work is the co-imbrication of the processes whereby human beings determine, reconfigure, or transform the subjects and objects of pleasure/ desire alongside the processes of the global reproduction of this new "pharmacopornographic" subjectivity. ${ }^{50}$

But Testo Junkie does not paint a pretty picture if what we want is an explicitly queer and liberatory politics since it defines today's

50 "There is nothing to discover in sex or in sexual identity; there is no inside. The truth about sex is not a disclosure; it is sexdesign... The pharmacopornographic business is the invention of a subject and then its global reproduction." Beatriz Preciado, Testo Junkie: Sex, Drugs, and Biopolitics in the Pharmacopornographic Era, trans. by Bruce Benderson (New York: The Feminist Press, 2013), 36 . struggle as the project for the re-appropriation of the global production of substances and images; and all in order to reorganize this productive process in order to construct a world where our substance use and erotic excitement fundamentally breaks with the histories of exploitation, colonization, etc. To his credit, however, it is an analysis that helpfully explains how the social problems generated by capital (depression, sickness, anxiety, etc.) double as the ground for value production - it shows that the nature of the achievements of technological development subsumed to market demand is a success in terms of "transforming our depression into Prozac, our masculinity into testosterone, our erection into Viagra, our fertility/sterility into the Pill."51 To affirm the project of Testo Junkie only gets us further away from the question since Preciado's view includes the following three claims by necessity: (i) queerness and queer politics have outlived their usefulness (what is truly useful is a techno-experimental subject); (ii) the current relationship between the human and non-human species is not seen as being a source of possible moral dilemma (the continued use of non-human species for our technogenders is not seen as problematic); and (iii) we should aim to repurpose our powers of determining just exactly what it is we desire and how we go about

51 Preciado, Testo Junkie, 34-5. 
satisfying its demands (a goal that potentially overestimates the capacities of contemporary subjectivity). So while biology may never have been our destiny, there still exists a destiny for our biology: and a destiny that is increasingly being determined by the reproduction of our technogendered subjectivity. ${ }^{52}$

JJG: Autumn last year I attended Folsom Europe, the continent's largest gathering of leathermen. There were many sensual delights while strolling through the packed crowd filling Fuggerstraße: many couples had matching PVC outfits, some wore telltale yellow rubber, one man was being led through the throng by another while leashed and blindfolded. My overriding memory, however, was the puppies.

Puppy play has blossomed in popularity among gay men, and at this point has an autonomous character which exists both within and beyond leather culture more generally. Puppies have an unmistakably uniform attire: prominent hound masks, leather straps or skintight suits across their torso, and perky tails. The result of being clad in so much black PVC was that their bodies seemed slender, their move-

52 "Gender in the twenty-first century functions as an abstract mechanism for technical subjectification; it is spliced, cut, moved, cited, conceived of as design [..] No political power exists without control over production and distribution of gender biocodes. Pharmacopornographic emancipation of subaltern bodies can be measured only according to these essential criteria: involvement in and access to the production, circulation, and interpretation of somato-politic biocodes." Preciado, Testo Junkie, 129. ments were defined by a center of gravity drawn down to embrace the pavement. When not in motion they rested on their haunches, panting, blithely oblivious to street dirt.

While an admirer, I personally have never felt an obvious fit for the leather community, which is primarily based around intense informal ties of male sociality and successive ritualized initiation (the highest point of which is claiming and holding title: Mr. Rubber Sweden, Mr. New Jersey, and so on.) As a woman, I can only be some kind of outsider to this. (Leatherdykes are a proud tradition in their own right, but throughout Europe mostly a defunct one.) Leather culture has always idealized a cultivation of masculine vigor, an unabashedly gay manhood.

The puppies, however, were quite something else.

While those wearing them were exclusively (like over 9 from 10 of the crowd) male, a strangely androgynous aspect to their aesthetic struck me. Their carefree frolics and bounding energy lacked a decisively masculine spirit (unlike most outfits and postures on display around them). At once puppy players stray across norms of species behavior and regress to an impossible childhood. They were no longer men, but houndrogyne. To me these figures, yelping for attention and sprawling over pavements, seemed the exact reverse of the strut- 
ting Masc4Masc hulks which dominate most gay spaces. Rather than deny having ever been effeminate boys, as Eve Sedgwick had it, the puppies staged an unfamiliar and uncanny return. Upon remarking about this strange ambiguous character to a friend, they patiently replied: "They're not men or women, they're puppies!" 